\section{ZEW}

Zentrum für Europäische Wirtschaftsforschung GmbH

Centre for European Economic Research

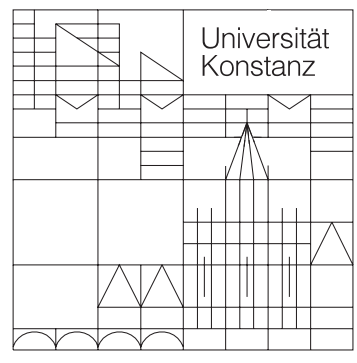

Rechts-, Wirtschafts- und Verwaltungswissenschaftliche Sektion Fachbereich

Wirtschaftswissenschaften

Diskussionspapiere der DFG-

Forschergruppe (Nr.: 3468269275):

Heterogene Arbeit: Positive und Normative Aspekte der Qualifikationsstruktur der Arbeit

David Audretsch, Erik Lehmann, Susanne Warning

University Spillovers: Does the Kind of Science Matter?

Februar 2004 
Diskussionspapier der Forschergruppe (Nr.: 3468269275) "Heterogene Arbeit: Positive und Normative Aspekte der Qualifikationsstruktur der Arbeit"

Nr. 04/04, Februar 2004

\section{University Spillovers: Does the Kind of Science Matter?}

\section{David Audretsch}

Max Planck Institute Jena, Indiana University, and CEPR

Department Entrepreneurship, Growth and Public Policy

mail : audretsch@mpiew-jena.mpg.de phone :

fax : $+49-3641-68-6900$

\section{Erik Lehmann}

Universität Konstanz

Fach D 144

78457 Konstanz

Germany

mail : erik.lehmann@uni-konstanz.de

phone : +49-7531-88-2968

fax : $+49-7531-88-4456$
Susanne Warning

\author{
Universität Konstanz \\ Fach D 144 \\ 78457 Konstanz \\ Germany \\ mail : susanne.warning@uni-konstanz.de \\ phone : +49-7531-88-3359 \\ fax : $+49-7531-88-4456$
}

\section{Zusammenfassung:}

This study examines the impact of university spillovers on the locational choice of firm formation. Based on a unique and hand-collected data set of high-technology start-ups publicly listed in Germany, this paper tests the propositions that geographic proximity to the university is influenced by the kind of science and type of knowledge spillover. The results provide evidence that while academic research spillovers by articles and graduates seem to be less important as a location decision in the past, become a significant determinant for young and high-tech firms. 


\title{
University Spillovers: Does the Kind of Science Matter?
}

\author{
David B. Audretsch", Max Planck Institute Jena, Indiana University, and CEPR \\ Erik E. Lehmann ${ }^{* *}$, University of Konstanz \\ Susanne Warning ${ }^{* * *}$, University of Konstanz
}

January 30, 2004

This study examines the impact of university spillovers on the locational choice of firm formation. Based on a unique and hand-collected data set of high-technology start-ups publicly listed in Germany, this paper tests the propositions that geographic proximity to the university is influenced by the kind of science and type of knowledge spillover. The results provide evidence that while academic research spillovers by articles and graduates seem to be less important as a location decision in the past, become a significant determinant for young and high-tech firms.

Keywords: university spillover; firm location; entrepreneurship, social science, natural science

JEL: M13, L 20, R30

\footnotetext{
*Department Entrepreneurship, Growth, and Public Policy; Max-Planck Institute for Research into Economic Systems, Jena, Kahlaische Strasse 10, 07745 Jena, Germany. audretsch@mpiew-jena.mpg.de Fax: (+49)(0) 3641686900

** Department of Economics, University of Konstanz, Box D-144, 78457 Konstanz, Germany. Erik.Lehmann@uni-konstanz.de; Fax.: (+49) (0)7531 884456

Department of Economics, University of Konstanz, Box D-144, 78457 Konstanz, Germany. Susanne.Warning@uni-konstanz.de,Fax: (+49) (0)7531 884456

Financial support by the German Research Foundation (DFG) through the research group \#FOR454 "Heterogeneous Labor" at the University of Konstanz and the ZEW, Mannheim, is gratefully acknowledged. Furthermore, financial support of the Swiss National Bank is gratefully acknowledged. The paper benefited from presentations at the Academy of Management, Seattle (2003), the European Association of Research in Industrial Organization, Helsinki (2003), the DIW conference at the BerlinBrandenburg Academy of Science, and the Meeting of the European Economic Association in Stockholm (2003). All remaining errors are, of course, ours.
} 


\section{Introduction}

The production, acquisition, absorption, reproduction and disseminating of knowledge is seen as the fundamental characteristic of contemporary competitive dynamics and in fostering innovative activity (Sorensen and Audia 2000; Baum and Sorensen 2003; Varga 2000; Stuart and Shane 2002; Anselin et al., 2000; Santoro and Chakrabarti 2002). Within the field of innovation studies, technological change and knowledge spillover, the distinction between tacit and codified knowledge has been accorded great significance (Kogut and Zander 1992). While codified or explicit knowledge could be effectively expressed using symbolic forms of representation, this is not the case for tacit knowledge which defied such representation (Gertler 2003). If tacit knowledge is important for new and highly innovative firms and since tacit knowledge could not be easily transferred over large distances or bought via the market, it has become a major determinant in the competitiveness of regions and locations for those firms (see Porter and Stern 2001; Florida 2002).

However, there are some key questions regarding the locational decisions of firms that remain rather unexplored. First, while research has identified the important role that universities play in generating knowledge spillovers, their impact on the locational choice by firms remains unknown. Secondly, the mechanisms transmitting knowledge spillovers remain relatively unexplored. Thirdly, the actual knowledge spillover mechanism and firm location may also depend on the particular field of knowledge, i.e. social sciences or natural sciences. Finally, the importance of university spillovers and the role of tacit knowledge must be seen in a dynamic context. Since technological change goes together with knowledge-based activities, one should expect that the impact of academic research on the location decision has also changed. 
However, there is no theoretical reason to expect either the mechanism transmitting knowledge spillovers or its impact on locational decisions to be invariant across different academic disciplines. Thus, the purpose of this paper is to address these questions focusing on whether knowledge spillovers are homogeneous with respect to different scientific fields. We do this by linking the locational choice of firms in terms of proximity to a university to the research and educational outputs of universities. By distinguishing between natural science and social science research outputs, as well as between students and graduates in the natural sciences and social sciences, this paper analyzes a data set consisting of 281 publicly listed firms in German high technology and knowledge industries. However, since theory provides relatively little guidance as to what extent social sciences and natural sciences influence firm location, our paper consists of much descriptive data analysis as formal hypothesis testing. Also distance to universities is only one determinant of firm location, our conclusions are quite more speculative since other variables are not considered in this study.

In particular, we find compelling evidence suggesting that firms have a high propensity to locate close to universities. However, the role that geographic proximity plays is shaped by the particular knowledge context and the communication channel. The more generic nature of social sciences renders geographic location less important in absorbing knowledge from academic research. However, it appears that location matters more in the natural sciences, which presumably reflects the specialized nature of scientific knowledge.

This paper also identifies one particular mechanism transmitting the spillover of knowledge. Graduates and students serve as a conduit for transmitting knowledge from the university where it is created to a firm where it becomes commercialized. 
Splitting the dataset reveals that the impact of academic research and students on firm location changed in the last decade. Firms younger than the median firm (eight years) are located significantly closer to universities with a high number of articles published in natural sciences and with a high number of students and graduates in both academic fields. In contrast, academic research and students seem to have no statistically significant impact on firm location for older firms. This however, with one exception: the existence of technical universities. ${ }^{1}$ Those universities with their specialization in engineering and machinery enter the regression significantly in the subsample with older firms, but not in the subsample with younger firms. This result reflects the structural change towards an entrepreneurial economy as proposed by Audretsch and Thurik (2001). Since the entrepreneurial economy is based less on traditional inputs and more on the input of knowledge, entrepreneurs should consider this restriction and thus decide to locate closer where those inputs could be found.

The remainder of the paper is organized as follows: section 2 summarizes the literature and introduces the four testable hypotheses raised in this paper. Section 3 contains the description of the database, and the estimation techniques. The empirical results are presented in section 4 . In section 5 a summary and conclusions are presented.

\section{University spillovers, tacit knowledge, and firm location}

University spillovers could be defined as an externality accessed by firms, for which the university is the source of the spillover but not fully compensated (Harris, 2001). Because firms access external knowledge at a cost that is lower than the cost of

\footnotetext{
${ }^{1}$ We would like to thank an anonymous referee for this comment.
} 
producing this value internally or of acquiring it externally from a larger geographic distance (Harhoff 2000), they will exhibit higher expected profits. The cost of transferring such knowledge is a function of geographic distance and gives rise to localized externalities (Siegel et al. 2003).

Such spillovers may arise from personal networks of academic and industrial researchers (Liebeskind et al. 1996; MacPherson 1998; Feldman and Desroche 2003), participation in conferences and presentations, or fresh candidates as an important channel for disseminating the latest knowledge from academia to high-technology industry (Varga 2000). University research, as the source of such spillovers, is measured by the amount of money spent on Research and Development (R\&D), the number of articles published in academic and scientific journals, the number of employees or patents (see Varga, 2000; Henderson et al. 1998; Hall et al. 2003; McWilliams and Siegel 2000). The overwhelming part of the empirical literature confirms the positive effects of university spillovers (Acs et al. 1992; 1994; Jaffe et al. 1993; Audretsch and Feldman 1996; Anselin et al. 1997; Varga 2000; Mowery and Ziedonis 2001).

However, there are only few papers which explicitly analyze entrepreneurship and newfirm start-ups as conduits for knowledge spillovers. Bania et al. (1993) analyze the frequency of high-technology start-ups and find only a small effect of university research funding on the start-up rate. Audretsch and Stephan $(1996 ; 1999)$ use joint papers of researchers and practitioners. They show that the spillover of knowledge to a new firm start-up facilitates the appropriation of knowledge for the individual scientist but not necessarily for the organization creating that new knowledge in the first place. Also Zucker et al. (1998) link universities and start-ups in biotechnology by academic articles. They demonstrate that not spillover effects per se but rather the intellectual 
capital of star-scientists plays a major role in shaping both the location and timing of the entry of new firms. Shane (2001a;b) explores the determinants of proximity to the MIT (Massachusetts Institute of Technology) on new firm formation. His main finding is that universities create technological spillovers which could be exploited by the formation of new firms.

However, it remains an open question whether new firms are generally able to exploit technological spillovers created by universities or if they are only able to commercialize product innovations (as shown by Mowery and Ziedonis 2001).

Our first hypothesis is based on the findings by Audretsch and Stephan (1996; 1999) among others, who present different impacts of tacit knowledge and codified knowledge on the locational benefits of geographic proximity to a university. Strict adherence to the scientific method assures that academic research embodies a high component of codified and specific knowledge in the natural sciences (Stephan 1996). By contrast, the more limited applicability of the scientific method implies that research in the social sciences will embody less codified knowledge (Stephan 1996). In contrast, academic research in the natural sciences is more codified and thus does not require a short distance to absorb the spillover effects. Because of its high codification, scientific knowledge can be largely accessed by (competently) reading scientific journals. Thus, we assume that knowledge in the social sciences is more tacit and less codified, rendering geographic proximity to be more important in accessing knowledge spillovers.

The second hypothesis is based on the distinction between codified and tacit knowledge (Kogut and Zander 1992). Elements of know-how and operations cannot be codified easily in a blueprint, a contractual document (Mowery and Ziedonis 2001), or a published article (Audretsch and Feldman 1996). Tacit knowledge needs oral 
communication and reciprocity which may be ineffective or infeasible over longer distances. As Jaffe (2001) points out, geographical location is important in capturing the benefits of spillovers when the mechanism of knowledge is informal, conversation, as is the case for tacit knowledge. Then, "....geographic proximity to the spillover source may be helpful or even necessary in capturing the spillover benefits" (Jaffe 1998, p.957). Thus, the limited geographic reach of such channels for the exchange of information and know-how is assumed to be one of the leading causes of the impact of geographic proximity since it leads to a competitive advantage over similar firms which are not located close to universities. This holds especially when high-skilled labor is a scarce resource and there is intense competition for human capital and other knowledge inputs (Porter and Stern 2001). This leads us to formulate our second hypothesis, which is that universities producing higher amounts of students and fresh graduates will attract firms to locate within a close geographic proximity.

Our third hypothesis states that students and graduates as a spillover mechanism should be different than from published scientific articles. While scientific articles serve as an effect conduit of transmitting codified knowledge in the natural sciences, they are more limited in transmitting the high degree of tacit knowledge in the social sciences. By contrast, geographic proximity may be less important for accessing knowledge transmitted by recent graduates in the social sciences than in the natural sciences. This is because of the generic nature of university education in the social sciences in Germany. Social science programs are standardized throughout the country, which produces graduates with a relatively homogeneous degree of human capital. However, such standardization is not found in the natural sciences, so that geographic proximity is important to access knowledge embodied in recent graduates in the natural sciences. 
Therefore, the number of fresh graduates in social sciences would not really affect the firms' decision to locate close towards the next university. In contrast, we assume that fresh graduates differ in natural sciences. In this field, universities differ in their specific research specialization like life-science, biochemistry, physics, or engineering. Thus, the human capital of fresh graduates and students in the natural sciences is likely to be more "specific" than "general". Thus, we expect that universities with a high amount of students in the natural sciences will attract firms to locate within a closer geographic proximity.

Finally, we expect that academic spillovers as a determinant of firm location are not time invariant. The structural change from traditional production towards a high-tech and service-oriented business in Germany, as described by Audretsch and Thurik (2001) or Audretsch and Fritsch (2003), should be reflected by the data. If tacit knowledge is more important for young and highly innovative firms and was less important in the past, then the locational decision towards universities should differ between younger and older firms. Especially, we expect that academic spillovers are important for young firms reflecting the structural change in the past decade and were less important for start-ups before.

\section{Data, Measurement, and Methodology}

To test the hypothesis that firm foundation depends on geographical proximity to a university, we use a unique dataset of high-technology German firms publicly listed on the Neuer Markt. The total number of German firms listed on the Neuer Markt, Germany's counterpart of the NASDAQ, was 295 between 1997 and 2002. From these 
firms we dropped 5 banks and 9 holding companies. The dataset is collected combining individual data from IPO prospectuses, along with publicly available information from on-line datasources including the Deutsche Boerse $A G$ (www.deutsche-boerse.com). We use this database for several reasons. First, the sample includes highly innovative industries, like biotechnology, medical devices, life sciences, e-commerce and other high-technology industries which represent the knowledge-based economy. Secondly, studies from the U.S. provide strong evidence for the growth effect of clusters influenced by the presence of research-active university (Feldman, 2000). This dataset enables us to follow this line of research. Thirdly, this data set represents the technological change in the German Business sector from the predominance of mediumsized firms in the production and manufacturing towards the high-technology and service sector, characterized by the importance of intangible assets in contrast to fixed capital. Finally, in Germany such data are not available for privately-held firms.

We pooled this dataset by adding university-specific variables, which are individually collected from the 73 universities in Germany. For each of those universities we collected the number of articles listed in the research database from the ISI (Information Sciences Institutes). Although this research database includes a small amount of all the journals in one field, it ensures that it only contains the high-quality research journals. We did not include research institutes since they only have a few graduates, if at all. Since German universities are not allowed to own assets on firms - in strong contrast to the U.S. - , there are no spin-offs in our dataset. However, we are not able to control for spin-offs by professors or other researchers.

To test the impact of universities on a firm's location decision, we take the DISTANCE to the closest university as the dependent variable. Since universities in Germany are more 
geographically concentrated compared to the U.S., we need a measure which is sensitive to small variations. The distance is measured in kilometers using the online database of the German Automobile Club (www.adac.de). All firms located within a radius of 1.5 kilometers are classified as belonging to the distance category of 1 kilometer. However, firm location could also be measured by geographic districts, compared to Metropolitan Statistical Areas (MSA) in U.S. studies (Varga 2000). To measure such effects, we construct the ordinary variable DISTRICT. This variable captures geographic proximity by focusing on the location closest to the university, within the same city and outside this area. The variable DISTRICT takes the value one if the firm is located within a close radius of 8 kilometers (the median value) around the university. If the firm is located within a radius of 20 kilometers the variable takes the value two, and three if the location is outside the radius of 20 kilometers.

Articles published in social sciences $(S S C I)$ are measured by the ISI-database SSCI (Social Science Citation Index). Articles in natural sciences $(S C I)$ are taken from the SCI (Science Citation Index). We included the number of listed papers for each university published from 1997 until 2000. We further control for students from science (SCISTUDENTS) and from social science (SSCISTUDENTS). We also control for the effect of the German Reunification by including a dummy variable indicating that a firm is located in West Germany (WEST). To control for the size of the city and other regional cluster effects, we include the log of the number of citizens (TOWN) and the number of universities (UNIVERSITIES) within the same city. Technical universities are assumed to play a special role in the technology transfer, since their focus is especially on engineering and natural sciences. A dummy variable is thus included to control for this special type of university $(T U)$. To capture time effects, we include the age of a firm 
$(A G E)$ which is measured in years from foundation to IPO. Finally, we also consider the amount of grants (GRANTS), the expenditures on staff (STAFF), and the number of all students (STUDENTS) of the respective university.

Since information about university expenditures or research grants are not annually or continuously published in Germany, we restrict our dataset to the year 1997, which is also the start of the Neuer Markt. However, the university system in Germany did not really change in the past decades, expenditures and the number of published articles remained nearly unchanged over the years. Comparing the articles published in SSCI and SCI journals since 1997 and a decade show a high bivariate correlation $(r>0.95)$. All monetary variables are measured in Deutsche Mark.

We apply three different estimation methods to test our hypothesis. First, we use simple OLS regression techniques with the distance, measured in kilometers, as the endogenous variable. Additionally, we apply negative binomial regressions, to consider that the variable DISTANCE is highly skewed. Since the variance of the dependent variable 'kilometers' is larger than the mean (see table 3), the variable is overdispersed and the Poisson regression technique is not applicable. Finally, firm location may also take part in the geographic district of a city. We thus apply ordered probit estimation to regress the explanatory variables on the variable DisTRICT. Especially, we estimate the following regression

distance $=$ const. $+\beta_{1}$ articles SCI $+\beta_{2}$ aricles SSCI $+\beta_{3}$ students SCI $+\beta_{4}$ students SSCI $+\beta_{5}$ grants $+\beta_{6}$ staff $+\beta_{7}$ total number students $+\beta_{8}$ west - dummy $+\beta_{9}$ city size $+\beta_{10}$ number of universities $+\beta_{11} T U-$ dummy $+\beta_{12}$ firm age $+\varepsilon$ 
While there are 72 public universities in Germany, only 52 of them could be identified as the closest university to a firm in the sample. As Tables 1 and 2 show, the university with the greatest impact on firm location and most impressive impact is the LudwigsMaximilian University (LMU) in Munich (see table 1 and 2). From the 281 firms included in the dataset, 51 firms chose to locate close to this university. This doubles nearly the 26 firms which located close to the University of Hamburg, followed by the Goethe University of Frankfurt (24 firms), the University of Stuttgart (16 firms) and the Humboldt University (HU) in Berlin (14 firms). Table 1 also offers some descriptive statistics of the top 20 universities as measured by the number of firms which are located closest to those universities.

Tables $3 \mathrm{a}$ and $3 \mathrm{~b}$ present the descriptive statistics. The closest location is one kilometer and the maximum distance is 177 kilometers away from the nearest university. The skewed distribution of the data is reflected by the difference between the mean and median values. While the arithmetic mean distance is about 17 kilometers, the median shows that $50 \%$ of the firms are located within an area with the radius of 7 kilometers. The $25 \%(75 \%)$ centile demonstrates that $25 \%(75 \%)$ of the firms are located within a small radius of 1 (21) kilometer(s). Thus, locational proximity to a university for the 281 firms in the data set is a first hint that university spillover effects influence the strategic location decision.

Tables 1 and 3 also indicate that research activities and the number of students varies considerably across universities. A comparison between the mean and median also exhibits the skewed number of articles in both the social sciences and natural sciences. On average, each university published about 250 papers in social sciences and more than 5,100 articles in natural sciences. However, the number of articles published by 
$50 \%$ of the universities is lower. Also the number of graduates differs across universities (see also table 1$)^{2}$

Interestingly, the number of articles and graduate students varies not only across universities but also across the two fields. While the mean university publishes twenty times more articles in the natural sciences compared to the social sciences, this difference increases with the number of published papers. However, articles in the natural sciences and those in social sciences differ in their length, number of co-authors and referee time, and are thus not comparable. While $50 \%$ of the universities publish about 200 articles in social sciences, there are more than 4,000 articles in the natural sciences. The opposite can be found for the number of students. On average, more than 20,300 students are studying social sciences, while only about a third, 7,300 are enrolled in the natural sciences. However, in most fields in the natural sciences, the number of students is restricted by the numerus clausus.

The data presented in table 3 a demonstrates that most of the firms are strikingly young. Half of the firms in our sample are eight years old or less, and $25 \%$ of the firms are younger than 3 years. About $90 \%$ of the firms are located in West Germany and about $9 \%$ are located close to one of the six technical universities (TU). More than $55 \%$ of the firms are located within a 8 kilometer circle around the university, about $20 \%$ between the inner circle and a 20 kilometer radius and the remaining rest of $23 \%$ are located outside the 20 kilometer radius.

Table 4 provides the correlation between the included variables. The high correlation between the articles published in SCI and SSCI demonstrates that universities are either

\footnotetext{
2 The University of Ulm (University of Erfurt) has no students in social science (natural sciences).
} 
research active - or not - independently from the academic field. Interestingly, there is a high correlation between the articles published in social sciences and the number of graduates in these fields, but not for natural science. While research in the social sciences seems to be not affected by the number of students in the natural sciences, there is a high correlation between the articles published in the natural sciences and the students in social sciences. One explanation may be that the natural sciences restrict themselves in the number of students (numerus clausus), while this is the case only for business economics and psychology in the social sciences. The high correlation between the number of students in the social sciences and the number of articles published in this field may also be due to size effects.

Another finding is the high correlation between research grants and the number of students in the natural sciences and the positive, even low, correlation with the number of articles published in this field. In contrast, research grants and the number of students as well as the number of articles do not seem to be correlated. However, research grants in the natural sciences exceed those in the social sciences by a multiple (see www.dfg.de)

\section{Academic Spillovers and Firm Location: Empirical Evidence}

We first employ a simple OLS approach to estimate the distance towards the closest university. The results are shown in table 5 (column 1). The number of students and graduates in both social and natural sciences enter the regression significantly in the predicted negative way. The higher the number of students and graduates in both academic fields, the closer the distance between the firm and the university. Since the 
spending on staff enters the regression significantly and positively and also the coefficient of the total number of students is positive but insignificant, the above finding could not be explained by size effects. In contrast, the number of articles in both social and natural sciences show no significant impact to explain some of the variation in the distance. The regression also points out that research-intense universities, expressed by the amount of research grants and the dummy variable indicating technical universities, are more successful to attract firms than others. Firms in larger cities are located closer to the next universities.

The results from the ordered probit model could not provide any significant results, except the significant and negative impact of town size. The lack of significant results may also be due to the sensibility of the specification of the distance circles. Therefore we continue our analyses by focussing on the more sensitive measure of distance in kilometers.

Considering the skewness of this dependent variable, we apply negative binomial regression techniques. The results are shown in column 3 in table 5. Now, however, the number of articles published in the natural science also enters the regression significantly negatively. This indicates that research-intense universities in the natural sciences are more attractive for start-ups. Again, the number of students and graduates in both fields significantly influence the locational decision.

Based on those results, we confirm that tacit knowledge, expressed and incorporated by the number of students and graduates highly influences the locational decision. Thus, fresh graduates and students serve as a conduit for transmitting knowledge from the university where it is created to a firm where it becomes commercialized. However, the more generic nature of social sciences renders geographic location less important in 
absorbing knowledge from academic research in social sciences.

To control for dynamic effects in absorbing university spillovers, we split the dataset into two groups and run separate regressions. ${ }^{3}$ Firms younger than the median age (eight years) are sampled in the first group. The second group contains thus firms older than the median firm. Although the variable age did not enter the former regressions significantly, the results do not differ extremely between both groups (see table 6).

While the first column in table 6 shows the results from the regression of the whole sample, the second and third column contain the estimations for the two subgroups. The first result is that tacit knowledge, as incorporated in fresh graduates and students, is more important for young firms, independently from the academic field. The negative coefficients of the number of students and graduates in both the natural and social sciences presumably reflect the high component of specific skills embodied in students and their importance for young firms. This finding provides evidence for the first hypothesis that universities with a higher amount of students and graduates attract firms to locate within a closer geographic proximity. Although this result holds also for the whole sample, the regressions on the subsample demonstrate that this holds especially for young firms. Thus, this finding also confirms the fourth hypothesis that academic spillovers are more important for firms founded in the $90 \mathrm{~s}$.

The second result is that academic research in the natural sciences enters significantly the regression for young firms but not for older firms. Also, academic research in the social sciences remains insignificant in all regressions. Although there is empirical evidence that academic articles are not an input per se (Zucker et al. 1998; Audretsch and Feldman 1999; Audretsch and Stephan 1996), the number of articles published in 
the natural sciences may also serve as a proxy for other academic research and outputs which could be commercialized by young firms. The insignificance of academic research in the social sciences could also be explained by the more generic nature of social sciences, which contradicts our second hypothesis. Although the results show that the kind of science matters, we cannot find evidence that academic research in the social sciences leads firms to locate closer towards the next university.

The third result is the role that technical universities play as a locational decision variable for older firms, but not for younger firms. Technical universities are well known for their research activities in engineering and machinery. This type of universities was especially established for the demand of German industries for skilled and trained engineers and academic research in this field (see Abramson et al. 1998). The result shows that while technical universities could satisfy this demand in the past, and thus act as a locational decision for those firms, they may fail to provide highskilled staff in other fields. In addition, this finding confirms our hypothesis that the importance of academic spillovers and the mechanisms of how academic research spills over have changed over time.

\section{Conclusions}

The results of this study not only confirm that university spillovers play an important role, but also that they have a strong influence in the strategic locational decisions of firms. However, the locational decision is shaped not only by the output of universities,

\footnotetext{
${ }^{3} \mathrm{We}$ are grateful to an anonymous referee for this suggestion.
} 
but also by the nature of that output. In this paper, we consider research and education in two different fields, the natural sciences and the social sciences, as outputs. To access knowledge transmitted by published articles in the social sciences, geographic proximity is particularly unimportant. The more generic nature of this academic field and its lower rate of new inventions and innovations makes it less important as a locational decision variable.

These results are actually reversed in accessing the educational output of universities, in the form of graduated students. Firms tend to locate in geographic proximity to universities with a high number of students and graduates in both the natural sciences and social sciences. This presumably indicates the limited geographic options for students with human capital specific to particular technologies and methods independently of the academic field.

The results of this paper suggest that while university spillovers are important in influencing the location of new and young high-tech firms, at least in the context of Germany, they appear to be sensitive regarding firm age. While young firms tend to locate closer to universities with a high academic output in the natural sciences and a high number of students and graduates in both the social and natural sciences, this does not hold for older firms. The dominance of technical universities to satisfy the demand in traditional German industries like engineering and machinery seems to diminish. Thus, while technical universities played an important decision variable for firm location in the past, this does not hold for younger, especially "New Economy" firms.

While this paper has considered only heterogeneous spillovers with respect to the natural sciences and social sciences and its impact for young and older firms, future 
research might focus on more finely delineated academic disciplines to identify more precise modes and magnitudes for knowledge spillover mechanisms.

\section{References}

Abramson, Norman H., Encarnacao José, Reid, Proctor P. and Schmoch, Ulrich 1998: Starting the Process: Technology Transfer in Germany, Chemtech, January 1998, 14- 21.

Acs, Zoltan J., Audretsch, David B. and Feldman, Maryann P. 1992: Real Effects of Academic Research: Comment, in: American Economic Review 82, 363367.

Acs, Zoltan J., Audretsch, David B. and Feldman, Maryann P. 1994: R\&D Spillovers and Innovative Activity, Managerial and Decision Economics 15, 131-138.

Anselin, Luc, Varga, Attila and Acs, Zoltan 1997: Local Geographic Spillovers between University Research and High Technology Innovations, Journal of Urban Economics 42, 422-448.

Anselin, Luc; Varga, Attila and Acs, Zoltan 2000: Geographical Spillovers and University Research: A Spatial Econometric Perspective, Growth and Change 31 (4), 501-515.

Audretsch, David B. and Feldman, Maryann P. 1996: R\&D Spillovers and the Geography of Innovation and Production, American Economic Review 86, 630-640.

Audretsch, David B. and Fritsch, Michael 2003: Linking Entrepreneurship to Growth: The Case of West Germany, Industry and Innovation 10, 65-73.

Audretsch, David B. and Stephan, Paula E. 1996: Company-Scientist Locational Links: The Case of Biotechnology, American Economic Review, 86 (3), 641-652.

Audretsch, David B. and Stephan, Paula E. 1999: Knowledge Spillovers in Biotechnology: Sources and Incentives, Journal of Evolutionary Economics 19, 97-107.

Audretsch, David B. and Thurik, Roy 2001: What's New about the New Economy? Sources of Growth in the Managed and Entrepreneurial Economies, Industrial and Corporate Change 19, 795-821.

Bania, Neil, Eberts, Randall and Fogerty, Michael S. 1993: Universities and the Start-up of New Companies: Can We Generalize from Route 128 and Silicon Valley?, Review of Economics and Statistics 75, 761-766.

Baum, Joel A. C. and Sorenson, Olav 2003: Advances in Strategic Management: Geography and Strategy, Vol. 20, JAI Press: Greenwich CT (forthcoming).

Feldman, Maryann P. 2000: Location and Innovation: The New Economic Geography of Innovation, in: Clark, G; Feldman, Maryann P., and Gertler, Meric (eds): Oxford Handbook of Economic Geography, Oxford University Press: Oxford. 
Feldmann, Marianne and Desroche, Pierre 2003: Research Universities and Local Economic Development: Lessons from the History of the John Hopkins University, Innovation and Industry 10, 5-24.

Florida, Richard 2002: Bohemia and Economic Geography, Journal of Economic Geography 2, 55-71.

Gertler, Meric, S. 2003: Tacit Knowledge and the Economic Geography of Context, or The undefinable tacitness of being (there), Journal of Economic Geography 3, 75-99.

Hall, Bronwyn H.; Link, Albert N. and Scott, John T. 2003: Universities as Research Partners, Review of Economics and Statistics, forthcoming.

Harhoff, Dietmar 2000: R\&D Spillovers, Technological Proximity, and Productivity Growth - Evidence from German Panel Data, Schmalenbach Business Review 52, 238-260.

Harris, Richard G. 2001: The Knowledge-Based Economy: Intellectual Origins and New Economic Perspectives, International Journal of Management Review 3, 21 41.

Henderson, Rebecca, Jaffe, Adam and Trajtenberg, Manuel 1998: Universities as a Source of Commercial Technology: A Detailed Analysis of University Patenting 1965-1988, Review of Economics and Statistics 65, 119-127.

Jaffe, Adam B. 1989: Real Effects of Academic Research, American Economic Review 79, 957-970.

Jaffe, Adam B., Trajtenberg, Manuel and Henderson, Rebecca 1993: Geographic Localization of Knowledge Spillovers as Evidenced by Patent Citations, Quarterly Journal of Economics 63, 577-598.

Kogut, Bruce and Zander, Udo 1992: Knowledge of the Firm, Combinative Capabilities, and the Replication of Technology, Organizational Science 3, 383-397.

Liebeskind, Julia, Amalya, Oliver, L.; Zucker, Lynne G. and Brewer, Marylin 1996: Social Networks, Learning, and Flexibility: Sourcing Scientific Knowledge in New Biotechnology Firms, Organizational Science 7, 428-443.

MacPherson, Alan D. 1998: Academic-industry Linkages and Small Firm Innovation: Evidence from the Scientific Instruments Sector, Entrepreneurship and Regional Development 10, 261-276.

McWilliams, Abigail and Siegel, Donald S. 2000: Corporate Social Responsibility and Financial Performance: Correlation or Misspecification?, Strategic Management Journal 21, 603-609.

Mowery, David C. and Ziedonis, Arvids A. 2001: The Geographic Reach of Market and Non-Market Channels of Technology Transfer: Comapring Citations and Licenses of University Patents, NBER working paper No. 8568.

Porter, Michael E and Stern, Scott 2001: Innovation: Location Matters, MIT Sloan Management Review, Summer 2001, 28-36.

Rosenberg, Nathan and Nelson, Richard R 1994: American Universities and Technological Advance in Industry, Research Policy 23, 323-348.

Santoro, Michael D. and Chakrabarti, Alok K. 2002: Firm Size and Technology Centrality in Industry-University Interactions, Research Policy 31, 11631180. 
Shane, Scott 2001a: Technological Opportunities and New Firm Creation, Management Science 47, 205-220.

Shane, Scott 2001b: Technology Regimes and New Firm Formation, Management Science 47, 1173-1190.

Siegel, Donald S., Westhead, Paul and Wright, Mike 2003: Assessing the Impact of Science Parks on the Research Productivity of Firms: Exploratory Evidence from the United Kingdom, International Journal of Industrial Organization (forthcoming).

Sorensen, Olav and Audia, Giuseppe 2000: The Social Structure of Entrepreneurial Activity: Geographic Concentration of Footwear Production in the U.S, 1940-1989, American Journal of Sociology 106, 324-362.

Stephan, Paula 1996: The Economics of Science, Journal of Economic Literature 34 (3), 1199-1235.

Stephan, Paula E.; Sumell, Albert J.; Black, Grant C. and Adams, James D. 2002: Public Knowledge, Private Placements: New Ph.D.s as a Source of Knowledge Spillovers, working paper, Georgia State University.

Stuart, Toby E. and Shane, Scott 2002: Organizational Endowments and the Performance of University Start-ups, Management Science 48, 151-170.

Varga, Attila 2000: Local Academic Knowledge Transfers and the Concentration of Economic Activity, Journal of Regional Science 40, 289-309.

Zucker, Lynne G.; Darby, Michael R. and Armstrong, Jeff 1998: Intellectual Human Capital and the Birth of U.S. Biotechnology Enterprises, American Economic Review 88 (1), 290-306. 
Table 1: List of the Top 20 universities

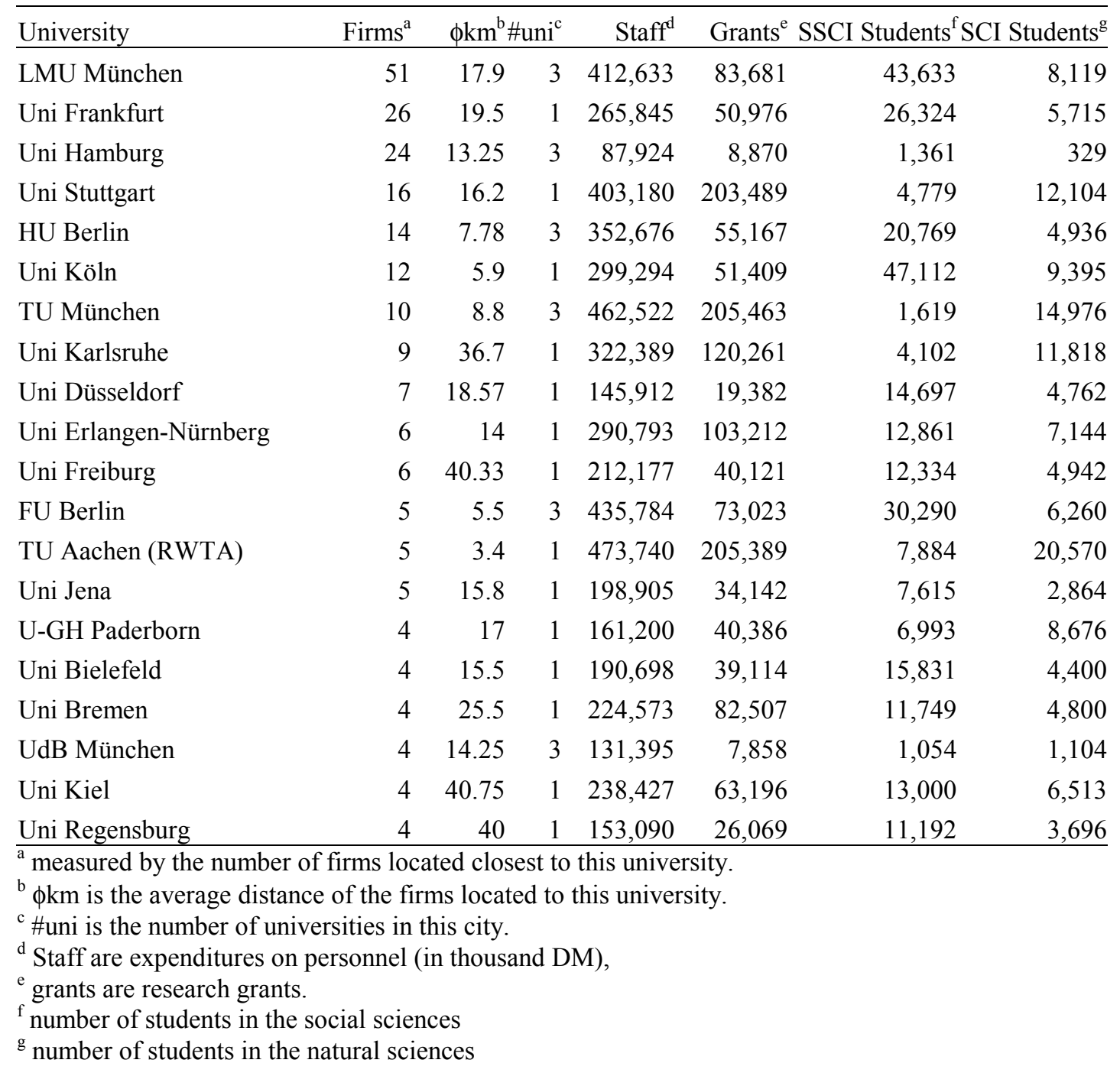

Table 2: Frequency of the number of universities

\begin{tabular}{|l|l|l|l|l|l|l|l|l|l|l|l|l|l|l|l|}
\hline Frequency & 1 & 2 & 3 & 4 & 5 & 6 & 7 & 9 & 10 & 12 & 14 & 16 & 24 & 26 & 51 \\
\hline Universites & 14 & 8 & 9 & 7 & 3 & 2 & 1 & 1 & 1 & 1 & 1 & 1 & 1 & 1 & 1 \\
\hline
\end{tabular}


Table 3a: Descriptive Statistics

\begin{tabular}{lccccccc}
\hline & Mean & Std. Dev. & Min & Max & $25 \%$ Cent & Median & $75 \%$ Cent \\
\hline kilometers & 16.69 & 23.45 & 1 & 177 & 1 & 7 & 21 \\
SCI & $5,139.43$ & $4,603.16$ & 0 & 14,176 & 2,179 & 4,069 & 5,924 \\
SSCI & 253.86 & 220.01 & 0 & 659 & 56 & 204 & 465 \\
SCI-Grads & $20,321.17$ & $15,409.63$ & 0 & 47,112 & 6,961 & 15,741 & 30,290 \\
SSCI-Grads & $7,304.89$ & $3,988.45$ & 0 & 20,570 & 4,936 & 7,725 & 9,395 \\
Firm age (years) & 10.27 & 11.11 & 0.1 & 107 & 3 & 8 & 14.25 \\
Grants (thousand DM) & $73,767.37$ & $53,420.03$ & 44 & 205,463 & 40,121 & 63,196 & 83,681 \\
Students & $28,030.82$ & $16,758,70$ & 5,430 & 56,507 & 16,549 & 22,603 & 38,239 \\
Universities & 1.83 & 0.95 & 1 & 3 & 1 & 1 & 3 \\
Staff (thousand DM) & $29,3028.6$ & $11,3090.6$ & 5,409 & 473,740 & 212,177 & 299,294 & 412,633 \\
Town (inhabitants) & $640,441.6$ & $897,371.4$ & 1,850 & 338,700 & 25,000 & 190,000 & $1,195,000$ \\
\hline
\end{tabular}

Table 3b: Descriptive Statistics

\begin{tabular}{lcccc}
\hline & Distance & Universities & West & Technical Universities \\
\hline Frequency (Percent) & $1: 157(55.9)$ & $1: 155(55.2)$ & West: $256(91.1)$ & TU: 25 (8.90) \\
& $2: 58(20.6)$ & $2: 16(5.7)$ & East: $25(8.9)$ & No TU: 91.1 (8.9) \\
& $3: 66(23.5)$ & $3: 110(39.1)$ & & \\
\hline
\end{tabular}

Table 4: Correlation Matrix

\begin{tabular}{lccccccccc}
\hline & KM & $\begin{array}{c}\text { SCI- } \\
\text { Articles }\end{array}$ & $\begin{array}{c}\text { SSCI- } \\
\text { Articles }\end{array}$ & $\begin{array}{c}\text { SCI- } \\
\text { Students }\end{array}$ & $\begin{array}{c}\text { SSCI- } \\
\text { Students }\end{array}$ & Students & Grants & Staff & Town \\
\hline SCI & 0.012 & 1 & - & - & - & - & - & - & - \\
SSCI & -0.001 & 0.937 & 1 & - & - & - & - & - & - \\
SCI-Stud. & -0.043 & 0.219 & 0.057 & 1 & - & - & - & - & - \\
SSCI-Stud. & -0.043 & 0.776 & 0.877 & 0.072 & 1 & - & - & - & - \\
Students & -0.05 & 0.808 & 0.862 & 0.307 & 0.970 & 1 & - & - & - \\
Grants & -0.038 & 0.201 & -0.008 & 0.824 & -0.105 & 0.103 & 1 & - & - \\
Staff & -0.074 & 0.640 & 0.527 & 0.728 & 0.491 & 0.650 & 0.747 & 1 & - \\
Town & -0.331 & 0.017 & 0.121 & -0.173 & 0.180 & 0.131 & -0.103 & 0.188 & 1 \\
Age & 0.106 & -0.002 & -0.012 & 0.099 & 0.056 & 0.014 & 0.0567 & 0.053 & -0.114 \\
\hline
\end{tabular}


Table 5: Geographic Proximity and the Kind of Science

\begin{tabular}{|c|c|c|c|}
\hline & $\begin{array}{c}\text { OLS } \\
{\text { (Kilometers })^{\mathrm{a}}}^{(\text {Kilo }}\end{array}$ & $\begin{array}{l}\text { Ordered Probit } \\
\text { (distance area) }^{\mathrm{b}}\end{array}$ & $\begin{array}{c}\text { NBR } \\
\text { (kilometers) }^{\mathrm{c}}\end{array}$ \\
\hline SCI & $-0.0019(1.46)^{\mathrm{d}}$ & $-0.00002(0.26)$ & $-0.00012(1.88)^{*}$ \\
\hline SSCI & $0.0165(0.54)$ & $-0.00093(0.58)$ & $0.00064(0.46)$ \\
\hline SCI students & $-0.0059(1.63)^{*}$ & $0.00009(0.44)$ & $-0.00027(1.73)^{*}$ \\
\hline SSCI students & $-0.0061(1.70)^{*}$ & $0.00002(0.11)$ & $-0.00031(1.95)^{*}$ \\
\hline Grants & $-0.0002(2.04)^{* *}$ & $-0.000005(1.07)$ & $-0.000015(3.32)^{* * *}$ \\
\hline Staff & $0.0001(3.23)^{* * *}$ & $0.0000005(1.48)$ & $0.000012(4.37)^{* * *}$ \\
\hline Students & $0.0054(1.47)$ & $-0.00008(0.43)$ & $0.00023(1.48)$ \\
\hline West & $-4.237(0.68)$ & $-0.3938(1.06)$ & $-0.5518(1.70)^{*}$ \\
\hline Town & $-0.00002(5.56)^{* * *}$ & $-0.000001(7.53)^{* * *}$ & $-0.000002(7.99)^{* * *}$ \\
\hline universities & $1.0130(0.43)$ & $0.19306(1.32)$ & $0.0813(0.56)$ \\
\hline $\mathrm{TH}$ & $-13.06078(1.90)^{*}$ & $-0.41461(1.14)$ & $-0.9419(3.04)^{* * *}$ \\
\hline Age & $0.08610(0.76)$ & $0.0106(1.38)$ & $0.0040(0.59)$ \\
\hline Constant & $20.0545(0.43)$ & - & $3.0151(7.11)^{* * *}$ \\
\hline Observations & 281 & 281 & 281 \\
\hline R-squared & 0.175 & 0.1609 & 0.0471 \\
\hline \multicolumn{4}{|c|}{$\begin{array}{l}{ }^{a} \text { Estimated OLS coefficients } \\
{ }^{b} \text { Estimated ordered probit coefficients } \\
{ }^{c} \text { Estimated negative binomial coefficients } \\
\text { Absolute t-values in parentheses } \\
{ }^{*} \text { Statistically significant at the } 10 \text { percent level } \\
{ }^{* *} \text { Statistically significant at the } 5 \text { percent level } \\
{ }^{* * *} \text { Statistically significant at the } 1 \text { percent level. }\end{array}$} \\
\hline
\end{tabular}


Table 6: Geographic Proximity and firm age

\begin{tabular}{|c|c|c|c|}
\hline & $\begin{array}{c}\mathrm{NBR}^{\mathrm{a}} \\
\text { (kilometers) }\end{array}$ & Young firms $^{\mathrm{c}}$ & Old Firms $^{\mathrm{d}}$ \\
\hline $\mathrm{SCI}$ & $-0.0120(1.88)^{\mathrm{b} *}$ & $-0.0170(1.72)^{*}$ & $-0.0048(0.54)$ \\
\hline SSCI & $0.0640(0.46)$ & $0.1393(0.66)$ & $0.0292(0.16)$ \\
\hline SCI students & $-0.0274(1.73)^{*}$ & $-0.0365(1.87)^{*}$ & $0.00009(0.03)$ \\
\hline SSCI students & $-0.0314(1.95)^{*}$ & $-0.0412(2.21)^{* *}$ & $0.00006(0.02)$ \\
\hline Grants & $-0.0015(3.32)^{* * *}$ & $-0.0016(1.99)^{* *}$ & $-0.0019(3.16)^{* * *}$ \\
\hline Staff & $0.0012(4.37)^{* * *}$ & $0.0011(2.62)^{*}$ & $0.0014(3.58)^{* * *}$ \\
\hline Students & $0.0235(1.48)$ & $0.0335(1.69)^{*}$ & $-0.0050(0.18)$ \\
\hline West & $-55.1860(1.70)^{*}$ & $-118.9204(2.31)^{* *}$ & $0.1147(0.29)$ \\
\hline Town & $-0.0002(7.99)^{* * *}$ & $-0.00001(5.45)^{* * *}$ & $-0.00001(5.61)^{* * *}$ \\
\hline universities & $8.1300(0.56)$ & $12.2254(0.55)$ & $0.1325(0.65)$ \\
\hline $\mathrm{TH}$ & $-94.1976(3.04)^{* * *}$ & $-52.3992(0.99)$ & $-149.4454(3.48)^{* * *}$ \\
\hline Age & $0.4004(0.59)$ & - & - \\
\hline Constant & $301.5117(7.11)^{* * *}$ & $368.156(5.54)^{* * *}$ & $223.0747(4.30)^{* * *}$ \\
\hline Observations & 281 & 145 & 136 \\
\hline R-squared & 0.0471 & 0.0546 & 0.0488 \\
\hline $\begin{array}{l}{ }^{\mathrm{a}} \text { Estimated neg } \\
\mathrm{b} \\
{ }^{\mathrm{C}} \text { Absolute t-val } \\
{ }^{\mathrm{c}} \text { Young firms } \\
{ }^{\mathrm{d}} \text { Old firms are } \\
{ }^{*} \text { Statistically si } \\
{ }^{* *} \text { Statistically si } \\
{ }^{* * *} \text { Statistically }\end{array}$ & $\begin{array}{l}\text { inomial coefficients. } \\
\text { parenthesis. } \\
\text { than nine years old } \\
\text { han the median. } \\
\text { int at the } 10 \text { percent le } \\
\text { int at the } 5 \text { percent ley } \\
\text { cant at the } 1 \text { percent }\end{array}$ & $\begin{array}{l}\text { icients are multiplied } \\
=8 \text { years }) .\end{array}$ & \\
\hline
\end{tabular}

